\title{
Sistem Informasi Pelayanan Perjalanan Ibadah Umrah
}

\author{
Wawan Setiawan ${ }^{1}$, Ani Oktarini Sari ${ }^{2}$ \\ ${ }^{1,2}$ Program Studi Sistem Informasi Universitas Bina Sarana Informatika \\ e-mail: ${ }^{1}$ wawansetiawan140414@gmail.com,${ }^{2}$ ani.aos@bsi.ac.id

\begin{tabular}{ccc}
\hline Diterima & Direvisi & Disetujui \\
$29-04-2020$ & $11-05-2020$ & $20-05-2020$ \\
\hline
\end{tabular}

\begin{abstract}
Abstrak - Perkembangan sistem pelayanan perjalanan ibadah umrah, tergolong cukup lambat dibanding dengan perkembangan sistem informasi yang lain, hampir semua perusahaan pelayanan perjalanan ibadah umrah, masih mempertahankan cara-cara konvensional yang menggunakan banyak pengumpulan dokumen fisik. Oleh karena itu, PT. Margi Suci Minarfa berencana menjadi salah satu perusahaan yang meninggalkan metode konvensioal dan beralih menggunakan tekonologi digital yang sedang berkembang yakni dengan menggunakan media website. Selain menjadi media promosi, website yang akan dibuat diharapkan mampu memberikan kemudahan akses bagi calon peserta umrah maupun bagi pihak perusahaan. Peserta umrah tidak lagi harus repot datang ke kantor untuk mengurus berkas-berkas karena upload dokumen dan pembayaran bisa dilakukan via website. Dan untuk staff dapat mengecek kelengkapan dokumen tersebut via website. Dalam pembuatan sistem informasi pelayanan perjalanan ibadah umrah ini menggunakan metode pengembangan sistem Waterfall. Pembuatan situs web, menggunakan framework CodeIgniter dan MySQL sebagai databasenya. Hasil dari penelitian ini akan menghasilkan website sistem informasi pelayanan perjalanan ibadah umrah yang dapat menghasilkan sistem informasi yang efektif dan efisien serta mempermudah dalam pengolahan data.
\end{abstract}

\section{Kata Kunci: Sistem Informasi pelayanan, pelayanan ibadah umrah, website perjalanan umrah}

Abstract - The development of the Hajj Umrah service system is quite slow compared to the development of other information systems, almost all Hajj Umrah service companies still maintain conventional methods which use a lot of physical document collection. . Therefore, PT. Margi Suci Minarfa plans to become one of the companies that abandoned conventional methods and went on to develop the use of digital technology website media. In addition to being a promotional support, the website to be created must be able to provide easy access to future Umrah participants and to the company. Umrah participants no longer have to worry about coming to the office to handle the files as documents and payments can be downloaded from the website. And for staff can check the completeness of these documents via the website. By creating this information system for the Umrah pilgrimage services using the cascade system development method. Website creation, using the CodeIgniter framework and MySQL as database. The results of this study will produce an information system website for the Hajj Umrah service which can produce an effective and efficient information system and facilitate data processing.

\section{Keywords: Information System Services, Umrah pilgrimage, Umrah travel website}

\section{PENDAHULUAN}

Di era digital ini, pola kehidupan masyarakat cenderung berubah. Pada saat ini, masyarakat cenderung memilih melakukan sesuatu secara praktis, mulai dari belanja, berangkat bekerja dan lain sebagainya. Pesatnya perkembangan teknologi, memaksa perusahaan-perusahaan untuk berkembang beriringan dengan teknologi juga. Banyak umat Islam yang menginginkan melaksanakan umrah sehingga dalam perkembangannya saat ini banyak sekali birobiro perjalanan wisata umrah (Aris, 2020).

Menurut (Susanti, 2015) menjelaskan tentang pelayanan, yaitu "menyeimbangkan surplus dan kerugian berbagai segmen pasar dan pelayanan melalui subsidi silang. suatu pengabdian atau pelayanan atau pemberdayaan sumber daya lainya dalam suatu kegiatan atau suatu organisasi untuk mencapai tujuan". Pengembangan sistem dalam perusahaan maupun sebuah instansi tersebut bertujuan untuk mendukung kelancaran pengolahan dan penyajian data, serta kemajuan dalam menyediakan informasi bagi manajemen dalam pengambilan keputusan dan menyediakan informasi bagi pihak lain diluar instansi, serta memberikan kemudahan pelayanan pada konsumen (Andriyani, Amin, \& Untari, 2019).

PT. Margi Suci Minarfa merupakan perusahaan yang bergerak dibidang pelayanan umrah. Nama travel yang digunakan adalah Minarfa Tour. Sistem pelayanan di Minarfa Tour masih menggunakan cara manual, seperti datang langsung lalu mengisi berbagai macam formulir, hal itu tentu saja kurang efisien. Setiap prosesnya, dimulai dari pelayanan sampai pemberitahuan pemberangkatan, masih dilakukan dengan cara datang langsung ke kantor. Keterbatasan media promosi paket haji dan 
umroh mengakibatkan kurangnya jangkauan penyebaran informasi kepada masyarakat (Prasetya, 2019). Pemanfaatan teknologi berbasis web juga dapat memberikan kemudahan dengan bertransaksi secara online kapan saja dan dimana saja tanpa mengkhawatirkan keterbatasan waktu dan tempat (Kosasi, 2016). Dengan menggunakan sistem basis data dan perancangan aplikasi yang terkomputerisasi, maka semua data dapat tersimpan dengan rapih, pengolahan data atau informasi dapat dilakukan dengan cepat, tepat dan akurat (Ardiyanto, 2020).

Tujuan dari penelitian ini adalah merancang sistem informasi pelayanan perjalanan ibadah umrah pada Minarfa Tour agar menghasilkan sistem informasi yang efektif dan efisien serta mempermudah dalam pengolahan data.

\section{METODE PENELITIAN}

Metode penelitian yang digunakan dengan melakukan observasi atau studi lapangan dengan melihat secara langsung proses kegiatan Pelayanan Perjalanan Ibadah Umrah di Minarfa Tour. Model pengembangan sistem yang digunakan adalah menggunakan model waterfall (Sukamto \& Shalahuddin, 2016) yang terbagi menjadi empat tahapan seperti berikut ini :

\section{Analisa Kebutuhan}

Dalam tahap ini melakukan analisa proses dan pengumpulan kebutuhan sistem yang sesuai dengan kebutuhan dan permasalahan yang ada. Dimana proses yang diamati dalam kegiatan yang berjalan di pelayanan jasa ibadah umrah, mulai dari pembentukan data paket, informasi data paket umrah, pendaftaran paket, informasi pembayaran dan sampai dengan laporan.

2. Desain

Proses desain ini membuat konsep pemodelan sistem dengan UML dan mempresentatifkan user interface dan desain database dengan menggambarkan ERD.

3. Pembuatan Kode Program

Pada tahap ini hasil desain dimasukkan kedalam bentuk bahasa pemrograman. Dalam implementasi ini dibuat dengan codeIgniter.

4. Testing

Pada tahap ini pengujian pada perangkat lunak dari segi fungsional dan memastikan bahwa semua bagian sudah diuji. Pengujian dilakukan dengan penggunaan blackbox testing. Sehingga diharapkan pengujian akan efisien karena hanya fokus di sisi fungsi saja dan untuk meminimalkan kesalahan dan memastikan output yang dihasilkan sesuai dengan yang diinginkan.

\section{HASIL DAN PEMBAHASAN}

\section{Analisa Kebutuhan Pengguna}

Adapun pengguna-pengguna yang dapat menggunakan fasilitas web ini sebagai berikut :

a. Petugas

1) Petugas dapat melakukan login

2) Petugas dapat melihat data calon peserta umrah.
3) Petugas dapat melihat detail kelengkapan dokumen peserta umrah.

4) Petugas dapat membuat info kepada peserta umrah

5) Petugas melakukan kelola data paket umrah

6) Petugas melakukan kelola data paket booking

7) Petugas melakukan kelola data paket bayar

b. Peserta Umrah

1) Peserta Umrah dapat melakukan pendaftaran akun.

2) Peserta Umrah dapat melakukan login.

3) Peserta Umrah dapat melihat info paket umrah.

4) Peserta Umrah dapat melakukan booking paket umrah.

5) Peserta Umrah dapat melihat info data diri dan mengupload dokumen.

6) Peserta Umrah dapat melihat info kegiatan.

7) Peserta Umrah dapat melakukan pembayaran

\section{Use case Diagram}

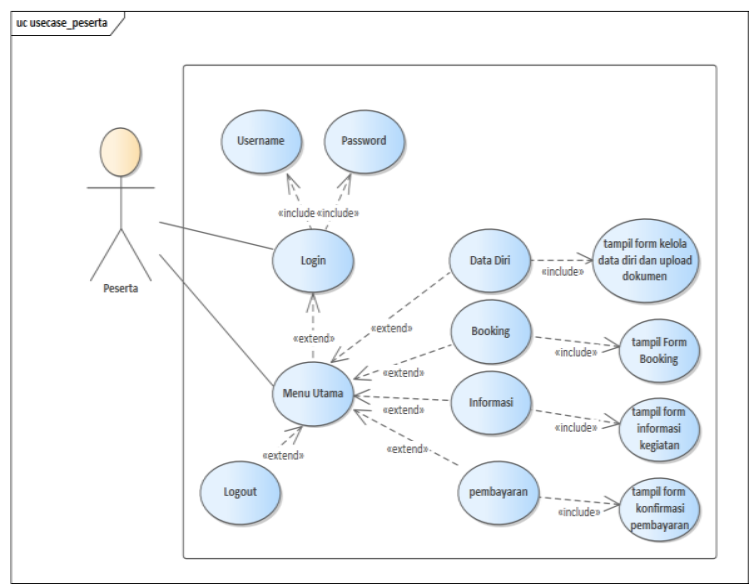

Sumber : Hasil Penelitian (2020)

Gambar 1. Use case diagram Peserta Umrah

Tabel 1. Deskripsi Use Case Akses Peserta Use Case Narative Akses Peserta Umrah

\begin{tabular}{|l|l|}
\hline Tujuan & $\begin{array}{l}\text { Aktor dapat melihat data } \\
\text { yang ada pada akses } \\
\text { Peserta }\end{array}$ \\
\hline Deskripsi & $\begin{array}{l}\text { Sistem ini } \\
\text { memungkinkan aktor } \\
\text { untuk dapat mengakses } \\
\text { kelola data pribadi dan } \\
\text { dokumen, kelola } \\
\text { pembayaran, melakukan } \\
\text { booking, dan melihat info } \\
\text { kegiatan. }\end{array}$ \\
\hline Skenario Utama & \multicolumn{1}{|c|}{} \\
\hline Aktor & $\begin{array}{l}\text { Aktor membuka web } \\
\text { tampilan akses peserta }\end{array}$ \\
\hline Kondisi Awal & \multicolumn{1}{|c|}{} \\
\hline
\end{tabular}




\begin{tabular}{|l|l|}
\hline Aksi Aktor & Reaksi Sistem \\
\hline $\begin{array}{l}\text { 1. Aktor melakukan } \\
\text { login }\end{array}$ & $\begin{array}{l}\text { Sistem ini menampilkan } \\
\text { proses login akses peserta }\end{array}$ \\
\hline $\begin{array}{l}\text { 2. Aktor melihat } \\
\text { informasi data diri }\end{array}$ & $\begin{array}{l}\text { Sistem ini menampilkan } \\
\text { informasi data diri dan } \\
\text { dokumen peserta yang } \\
\text { telah di upload }\end{array}$ \\
\hline $\begin{array}{l}\text { 3. Aktor melakukan } \\
\text { booking }\end{array}$ & $\begin{array}{l}\text { Sistem ini menampilkan } \\
\text { proses booking paket } \\
\text { umrah yang tersedia }\end{array}$ \\
\hline $\begin{array}{l}\text { 4. Aktor melakukan } \\
\text { konfirmasi } \\
\text { pembayaran }\end{array}$ & $\begin{array}{l}\text { Sistem ini menampilkan } \\
\text { proses pembayaran sesuai } \\
\text { kode booking yang sudah } \\
\text { dibuat }\end{array}$ \\
\hline $\begin{array}{l}\text { 5. Aktor melihat } \\
\text { informasi kegiatan }\end{array}$ & $\begin{array}{l}\text { Sistem ini menampilkan } \\
\text { informasi kegiatan yang } \\
\text { dipost oleh petugas }\end{array}$ \\
\hline Kondisi Akhir & $\begin{array}{l}\text { Jika perintah sesuai maka } \\
\text { sistem akan menampilkan } \\
\text { apa yang diinginkan }\end{array}$ \\
\hline
\end{tabular}

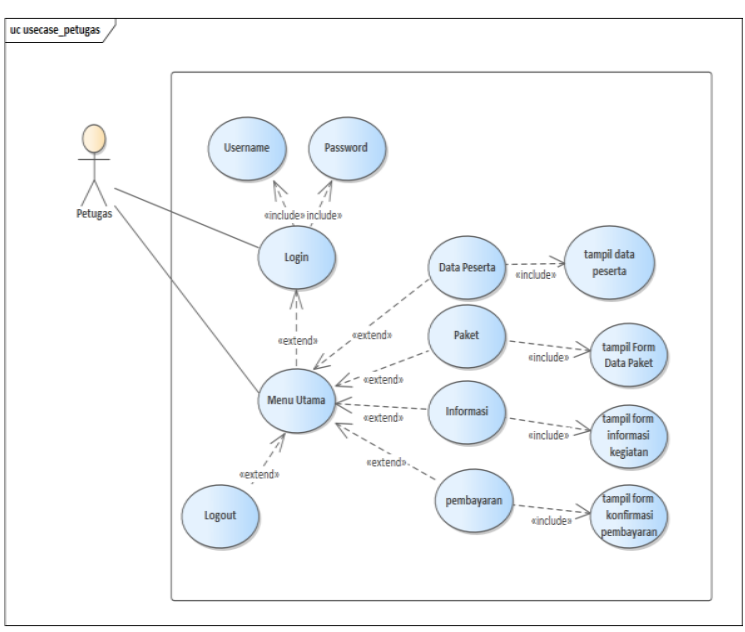

Sumber : Hasil Penelitian (2020)

Gambar 2. Use case diagram Petugas

Tabel 2. Deskripsi Use Case Akses Petugas

\begin{tabular}{|l|l|}
\hline \multicolumn{2}{|c|}{ Use Case Narative Akses Petugas } \\
\hline Tujuan & $\begin{array}{l}\text { Aktor dapat melihat data } \\
\text { yang ada pada akses } \\
\text { Petugas }\end{array}$ \\
\hline Deskripsi & $\begin{array}{l}\text { Sistem ini } \\
\text { memungkinkan aktor } \\
\text { untuk dapat mengakses } \\
\text { lihat data pribadi peserta } \\
\text { umrah dan dokumen yang } \\
\text { diupload, kelola data } \\
\text { paket, kelola } \\
\text { pembayaran, Kelola data } \\
\text { booking, kelola data } \\
\text { informasi }\end{array}$ \\
\hline Skenario Utama & Petugas \\
\hline Aktor
\end{tabular}

\begin{tabular}{|c|c|}
\hline Kondisi Awal & $\begin{array}{l}\text { Aktor membuka web } \\
\text { tampilan akses petugas }\end{array}$ \\
\hline Aksi Aktor & Reaksi Sistem \\
\hline $\begin{array}{l}\text { 1. Aktor melakukan } \\
\text { login }\end{array}$ & $\begin{array}{l}\text { Sistem ini menampilkan } \\
\text { proses login akses } \\
\text { petugas }\end{array}$ \\
\hline $\begin{array}{l}\text { 2. Aktor melihat } \\
\text { informasi data diri } \\
\text { peserta }\end{array}$ & $\begin{array}{l}\text { Sistem ini menampilkan } \\
\text { informasi data diri dan } \\
\text { dokumen yang telah di } \\
\text { upload oleh peserta }\end{array}$ \\
\hline $\begin{array}{l}\text { 3. Aktor melakukan } \\
\text { kelola data paket }\end{array}$ & $\begin{array}{l}\text { Sistem ini menampilkan } \\
\text { kelola data paket yang } \\
\text { nantinya akan tampil di } \\
\text { halaman front-end }\end{array}$ \\
\hline $\begin{array}{l}\text { 4. Aktor melakukan } \\
\text { kelola booking }\end{array}$ & $\begin{array}{l}\text { Sistem ini menampilkan } \\
\text { kelola booking paket } \\
\text { umrah yang telah } \\
\text { dilakukan peserta }\end{array}$ \\
\hline $\begin{array}{l}\text { 5. Aktor melakukan } \\
\text { kelola konfirmasi } \\
\text { pembayaran }\end{array}$ & $\begin{array}{l}\text { Sistem ini menampilkan } \\
\text { kelola proses pembayaran } \\
\text { yang telah dilakukan } \\
\text { peserta }\end{array}$ \\
\hline $\begin{array}{l}\text { 6. Aktor melakukan } \\
\text { kelola informasi } \\
\text { kegiatan }\end{array}$ & $\begin{array}{l}\text { Sistem ini menampilkan } \\
\text { kelola data informasi } \\
\text { kegiatan yang nantinya } \\
\text { akan tampil di halaman } \\
\text { peserta }\end{array}$ \\
\hline Kondisi Akhir & $\begin{array}{l}\text { Jika perintah sesuai maka } \\
\text { sistem akan menampilkan } \\
\text { apa yang diinginkan }\end{array}$ \\
\hline
\end{tabular}

Activity Diagram

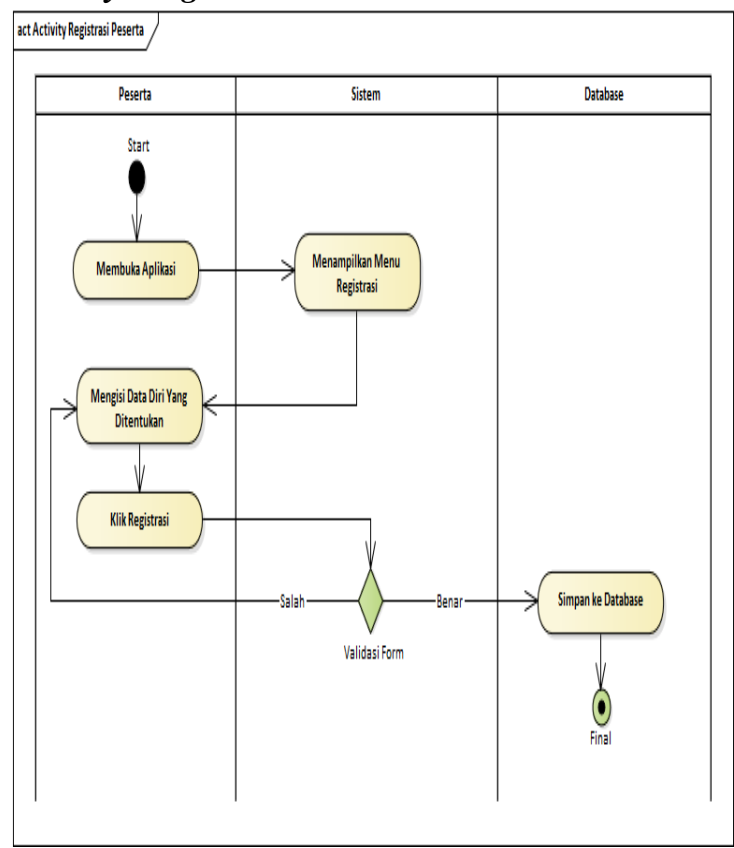

Hasil Penelitian (2020)

Gambar 3. Activity Diagram proses Registrasi

Peserta 
Entity Relationship Diagram (ERD)

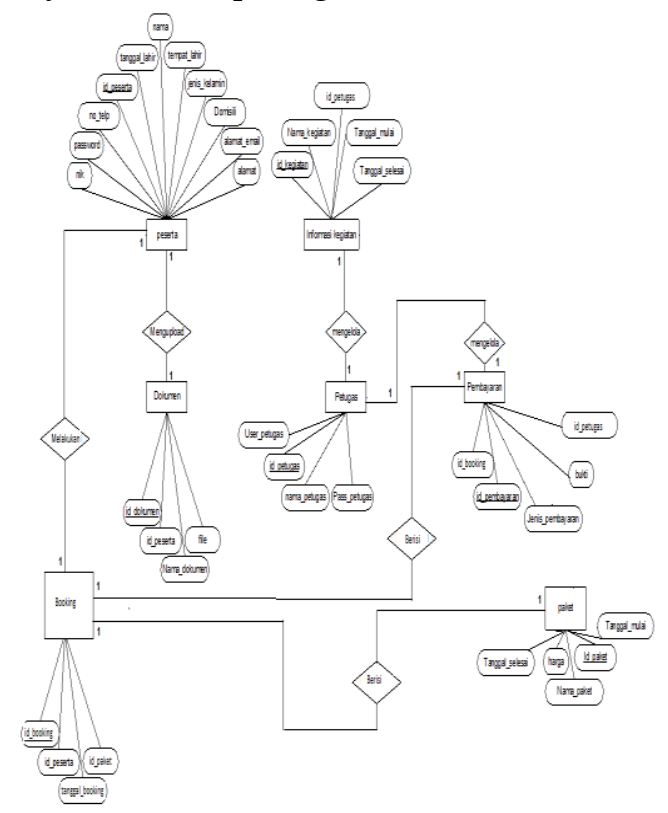

Sumber : Hasil Penelitian (2020)

Gambar 4. Rancangan database

\section{Logical Record Structure (LRS)}

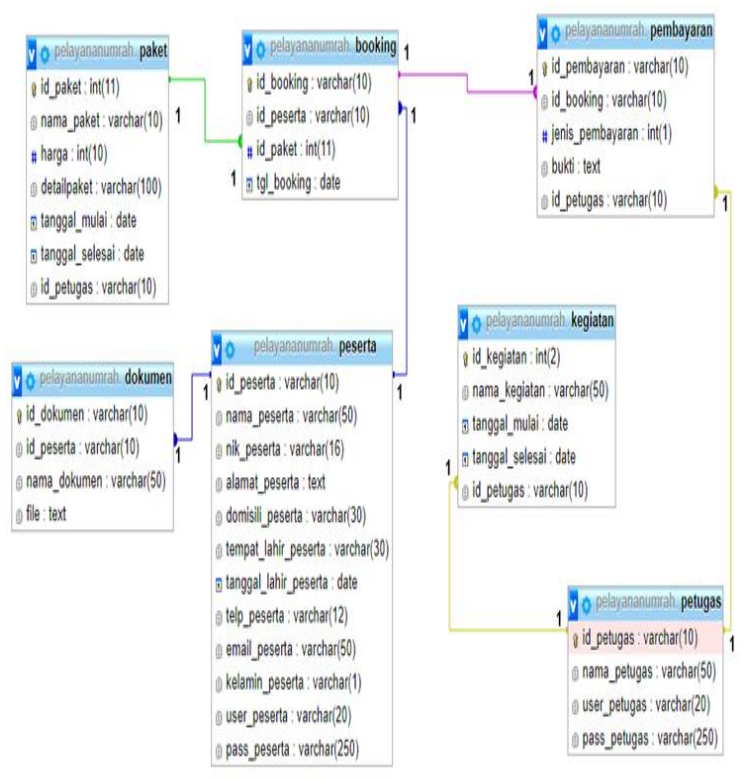

Sumber : Hasil Penelitian (2020)

Gambar 5. Rancangan database

\section{User Interface}

Berisikan implementasi hasil rancangan user interface yang dibuat tentang website informasi pelayanan jasa ibadah umrah Minarfa Tour.
1. Rancangan Front-end Pengunjung Web Halaman front-end sebagai media informasi tentang pelayanan perjalanan jasa ibadah umrah Minarfa Tour

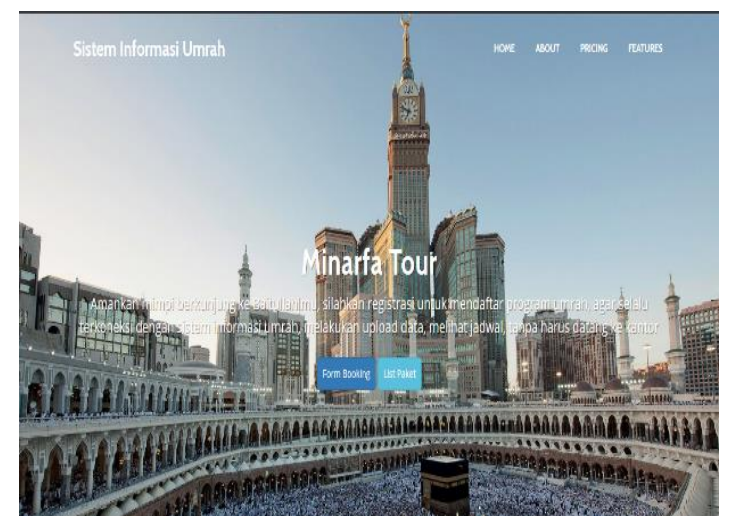

Sumber : Hasil Penelitian (2020)

Gambar 6. Halaman Front-end Pengunjung

2. Rancangan Registrasi Peserta

Calon Peserta umrah melakukan pengisian data awal Meliputi Nama lengkap, alamat email, nomor ktp, no telpon, tempat lahir peserta, tanggal lahir peserta, domisil, username, password, konfirmasi password, jenis kelamin, pilihan

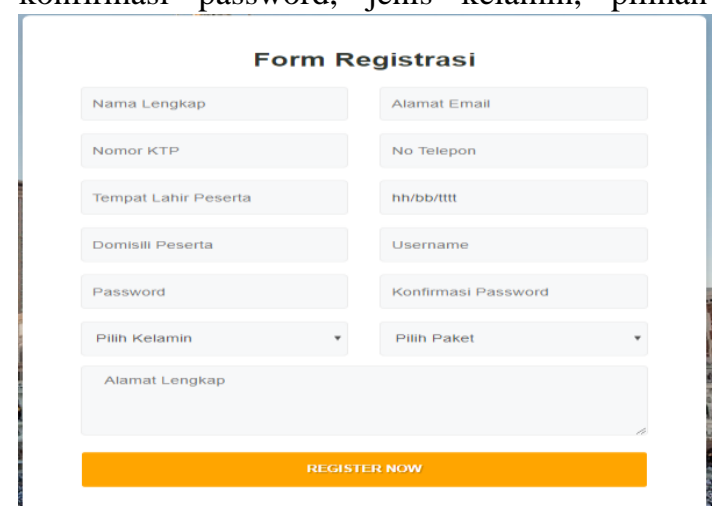

paket, alamat.

Sumber : Hasil Penelitian (2020)

Gambar 7. Registrasi Peserta

3. Rancangan login Peserta

Setelah melakukan registrasi maka, peserta umrah sudah resmi terdaftar pada web Minarfa Tour.

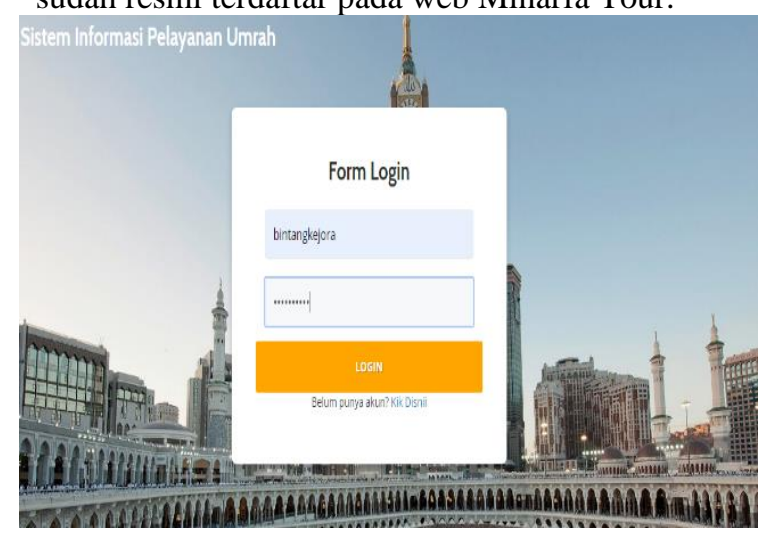

Sumber : Hasil Penelitian(2020)

Gambar 8. Login Peserta 
4. Rancangan Halaman Muka Peserta

Setelah melakukan akses login, peserta dapat melakukan update pembayaran, pengupload-an dokumen via laman halaman muka peserta

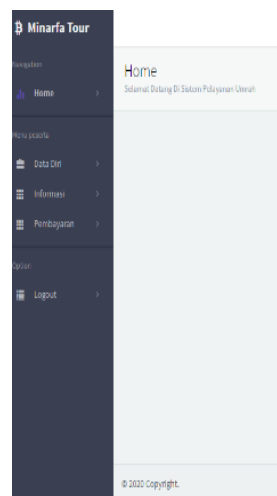

Sumber : Hasil Penelitian (2020)

Gambar 9. Halaman Muka Peserta

5. Rancangan Login Petugas

Untuk mengakses menu yang ada di halaman petugas, sebelumnya petugas diharuskan login dengan menginputkan username dan password yang telah terdaftar

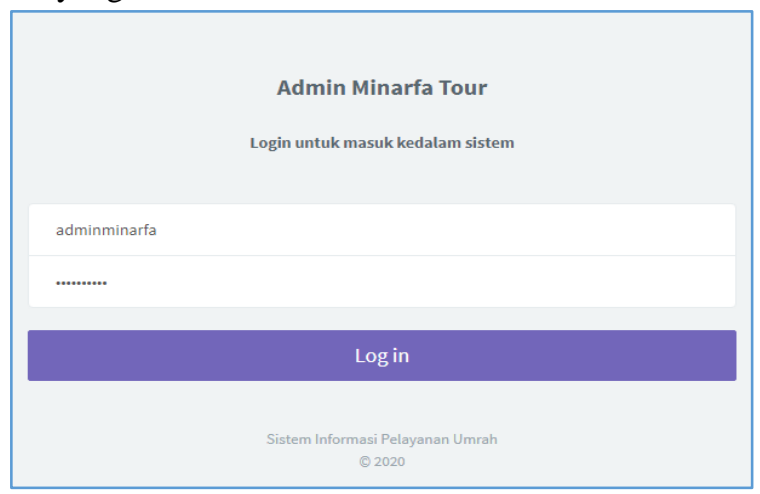

Sumber : Hasil Penelitian (2020)

Gambar 10. Halaman Login Petugas

\section{Rancangan Halaman Muka Petugas}

Pada halaman ini petugas dapat melakukan cek peserta, validasi data peserta, tambah paket, dan cek pembayaran peserta

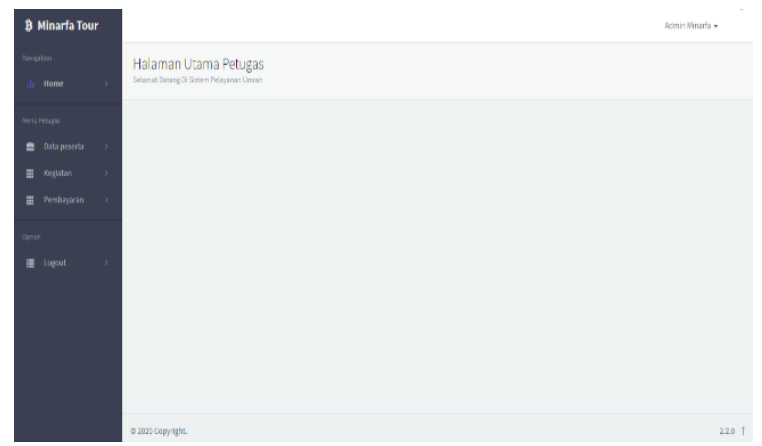

Sumber : Hasil Penelitian (2020)

Gambar 11. Halaman Halaman Muka Petugas
7. Rancangan Halaman Data Pembayaran Pada halaman ini petugas dapat melakukan cek pembayaran peserta yang telah dilakukan oleh peserta

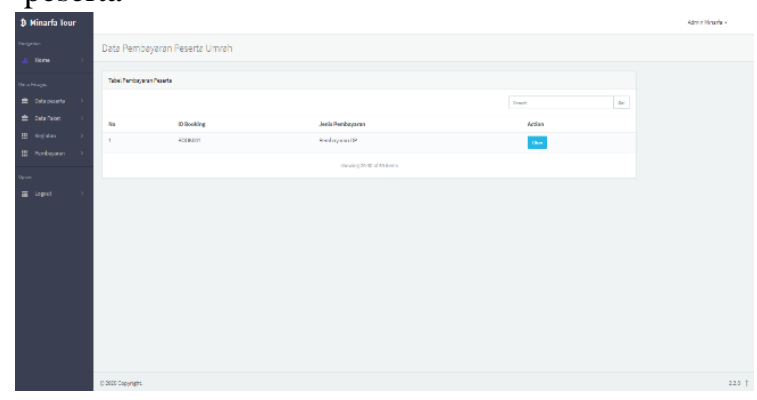

Sumber : Hasil Penelitian (2020)

Gambar 12. Halaman Data Pembayaran

8. Rancangan Halaman Informasi / Kegiatan Pada halaman ini petugas dapat melakukan menambah informasi mengenai informasi / kegiatan yang akan tampil pada halaman peserta

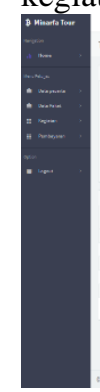

Sumber : Hasil Penelitian (2020)

Gambar 13. Halaman Data Iinformasi / Kegiatan

\section{Rancangan Halaman Data Paket}

Pada halaman ini petugas dapat melakukan menambah informasi mengenai Paket yang akan tampil pada halaman front-end website

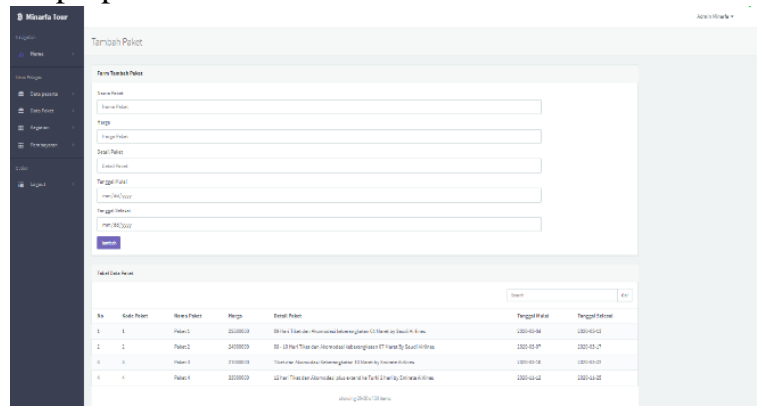

Sumber : Hasil Penelitian (2020)

Gambar 14. Halaman Data Paket 


\section{Pembuatan Kode Program}

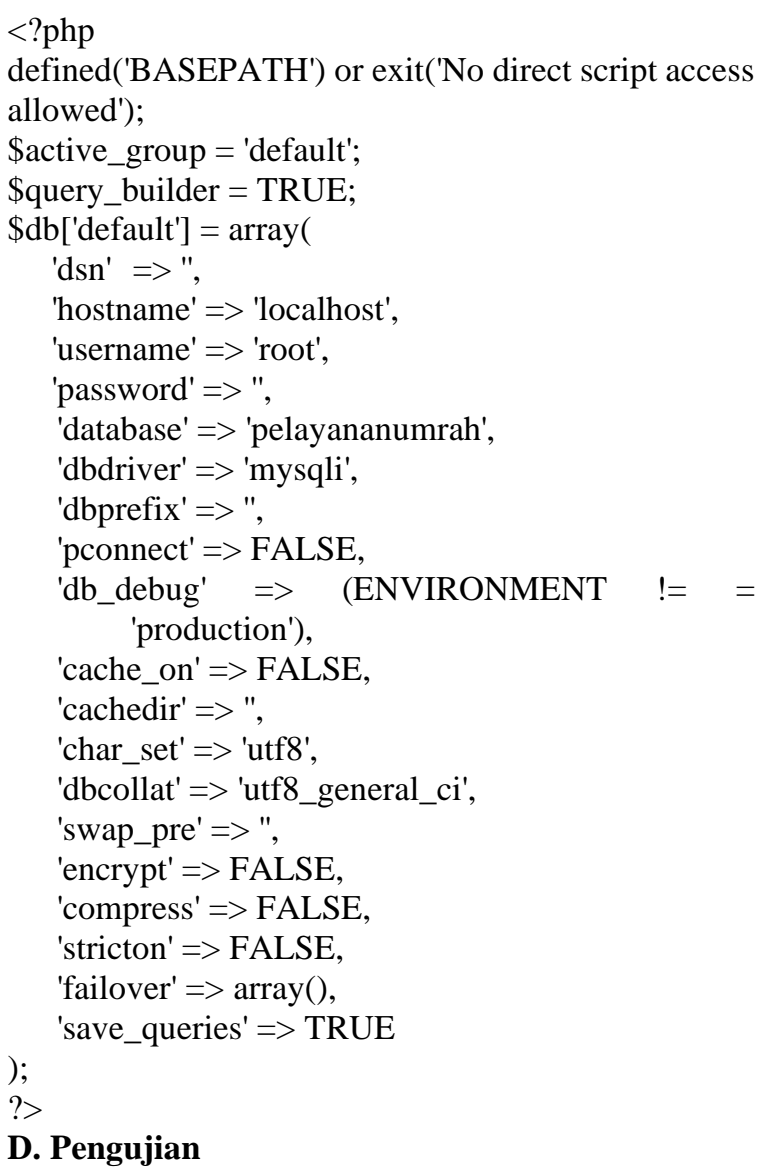

Pengujian program menggunakan blackbox testing dengan melakukan pengujian terhadap semua form, dan hasil pengujian telah sesuai harapan, kesimpulan seluruh testing progam adalah valid. Contoh pengujian blackbox testing pada login petugas dapat dilihat pada Tabel 3.

Tabel 3.

Blackbox testing Login petugas

\begin{tabular}{|c|c|c|c|c|c|}
\hline & $\begin{array}{l}\text { Skenario } \\
\text { Pengujian }\end{array}$ & Test Case & $\begin{array}{l}\text { Hasil Yang } \\
\text { Diharapkan }\end{array}$ & $\begin{array}{l}\text { Hasil } \\
\text { Penguji } \\
\text { an }\end{array}$ & $\begin{array}{c}\text { Kesimp } \\
\text { ulan }\end{array}$ \\
\hline 1 & $\begin{array}{l}\text { Jika } \\
\text { Semua } \\
\text { Data } \\
\text { petugas } \\
\text { tidak diisi } \\
\text { kemudian } \\
\text { klik } \\
\text { Simpan }\end{array}$ & $\begin{array}{c}\text { Nama } \\
\text { Petugas } \\
: \\
\text { (kosong) } \\
\text { Password } \\
: \\
\text { (kosong) }\end{array}$ & $\begin{array}{l}\text { Sistem } \\
\text { akan } \\
\text { menolak } \\
\text { proses } \\
\text { data } \\
\text { petugas } \\
\text { dan } \\
\text { menampil } \\
\text { kan pesan } \\
\text { "Data } \\
\text { Belum } \\
\text { Lengkap" }\end{array}$ & $\begin{array}{l}\text { Sesuai } \\
\text { Harapan }\end{array}$ & Valid \\
\hline 2 & $\begin{array}{l}\text { Jika salah } \\
\text { satu Data } \\
\text { petugas } \\
\text { tidak diisi } \\
\text { kemudian } \\
\text { klik } \\
\text { Simpan }\end{array}$ & $\begin{array}{c}\text { Nama } \\
\text { Petugas } \\
: \\
\text { (adminmi } \\
\text { narfa) } \\
\text { Password } \\
: \\
\text { (kosong) }\end{array}$ & $\begin{array}{l}\text { Sistem } \\
\text { akan } \\
\text { menolak } \\
\text { proses } \\
\text { data } \\
\text { petugas } \\
\text { dan } \\
\text { menampil } \\
\text { kan pesan } \\
\text { "Isi }\end{array}$ & $\begin{array}{l}\text { Sesuai } \\
\text { Harapan }\end{array}$ & Valid \\
\hline
\end{tabular}

\begin{tabular}{lclcl}
\hline & & Password & & \\
petugas" & & \\
3 Jika & Nama & Sistem & Sesuai & Valid \\
semua & Petugas & akan & Harapan & \\
Data & $:$ & proses & & \\
petugas & (adminmi & data & \\
diisi & narfa) & petugas & \\
kemudian & Password & dan & \\
klik & $:$ & menampil & \\
Simpan & $(* * * * * *)$ & kan pesan & \\
& & "Selamat & \\
& & Datang di & \\
& & halaman & \\
& & Petugas" & \\
\hline
\end{tabular}

\section{KESIMPULAN}

Dengan dibuatnya sistem informasi pelayanan umrah berbasis web ini, diharapkan mampu membuat proses bisnis pelayanan perjalanan ibadah umrah di PT. Margi Suci Minarfa menjadi lebih berkembang lagi. Dengan Sistem pelayanan secara online dapat meningkatkan efisiensi pelayanan, dari mulanya harus datang ke kantor, menjadi cukup menggunakan internet saja. Pembangunan sistem pelayanan umrah online dengan memanfaatkan web menjadikan sistem ini dapat diakses dimanapun, dikarenakan di era saat ini, hampir semua orang menggunakan internet dan mengakses web setiap harinya. Untuk pengembangan website ini masih terus dilakukan agar dapat mengakomodasi segala kebutuhan sistem yang terus berkembang setiap harinya.

\section{REFERENSI}

Abdulloh, R. (2018). 7 in 1 Pemrograman Web Untuk Pemula. Jakarta: Elex Media Komputindo.

Andriyani, A., Amin, I. H. Al, \& Untari, D. H. (2019). SISTEM INFORMASI RESERVASI PAKET WISATA DAN PAKET UMROH PADA PT PACIFIC TOURS MENGGUNAKAN METODE FIRST IN FIRST OUT (FIFO) BERBASIS WEB MOBILE. SINTAK, 3. Retrieved from https://unisbank.ac.id/ojs/index.php/sintak/artic le/view/7605

Ardiyanto, M. (2020). PERANCANGAN SISTEM INFORMASI HAJI DAN UMROH PADA OTTO PARIWISATA ARDANA TOUR Title. In Seminar Nasional Riset dan Teknologi (SEMNAS RISTEK) 2020 (pp. 70-76). Retrieved from http://proceeding.unindra.ac.id/index.php/semn asristek2020/article/view/1120\%0A

Aris, A. (2020). SISTEM INFORMASI PELAYANAN UMROH ALKHAIRAT GROUP BERBASIS WEB. Jurnal Ilmiah Informatika, 3(1), 213-219. Retrieved from https://journal.ibrahimy.ac.id/index.php/JIMI/a rticle/view/629

Kosasi, S. (2016). Perancangan Bisnis Toko Online untuk Memperluas Pangsa Pasar Aksesoris Produk Rohani. In Seminar Nasional Teknologi 
Informasi dan Multimedia.

Prasetya, W. S. (2019). PENERAPAN EXTREME

PROGRAMMING DALAM MEMBANGUN

SISTEM INFORMASI PELAYANAN HAJI

DAN UMROH (STUDI KASUS: PT. DAFA

PONTIANAK). In Seminar Nasional Sistem

Informasi dan Teknik Informatika (SENSITIf).

Ramadhan, S. F., \& Rusmawan, U. (2018). Membangun Aplikasi dengan PHP, Codeigniter, dan AJAX. Jakarta: PT Elex Media Komputindo.

Subagia, A. (2017). Membangun Aplikasi dengan CODEIGNITER dan Database SQL Server. Jakarta: PT Elex Media Komputindo.

Sukamto, R. A., \& Shalahuddin, M. (2016). Rekayasa Perangkat Lunak. Bandung: Informatika Bandung.

Susanti, Y. (2015). SISTEM PELAYANAN ONLINE, 11(2), 191-200. 